\title{
The Register-based Census in Germany: Historical Context and Relevance for Population Research
}

\author{
Rembrandt Scholz, Michaela Kreyenfeld
}

\begin{abstract}
In 2011, Germany carried out its first census after a 20-year break. In light of the United Nations' recommendations that countries initiate a population census at least every 10 years, the census was long overdue. Moreover, demographers had for some time been demanding a new enumeration that would enable them to place the calculation of demographic indicators on a reliable basis. With the 2011 census, Germany not only met the demand for a current population census, but also broke new ground by using a register-based approach. Unlike the Scandinavian countries, which have a long tradition of performing register-based data analyses, the linking of administrative data in Germany is restricted by the country's legal framework. Thus, the 2011 census was an ambitious project. After contextualising the 2011 census historically, we discuss in this contribution the census' relevance for generating central demographic data. Specifically, we compare the updated population estimates of the 1987 census to the results of the 2011 census in order to identify possible systematic sources of error that distort demographic indicators and analyses.
\end{abstract}

Keywords: Demographic indicators $\cdot$ Register data $\cdot$ Census

\section{Introduction}

The relevance of the census for demographic research is undisputed. It provides estimations of the population by age, sex, and region. This information is included in the calculation of demographic indicators, such as mortality, migration, nuptiality, and fertility rates. The census data also directly influence the results of survey data. The census provides the sampling frame for the microcensus, on which in turn the weights used in the social science surveys are based. However, the census' significance goes far beyond its relevance for demography and the social sciences. First, it provides the spatial distribution of the population, which is a prerequisite 
for the planning of municipal infrastructure projects. Second, the census results serve as a basis for the financial equalisation scheme between the German federal states, which regulates the distribution of public funds among the federal states and municipalities. Furthermore, the census results are relevant for the configuration of the constituencies (Wahlkreise) for national and federal elections, and they can influence the distribution of seats among the federal states in the German Federal Parliament (Bundestag). Thus, the German census is, like censuses in other countries, more than a data survey for the purposes of demographic and social research; it is, above all, a political issue. Or, with the words of Prewitt (2003: 1), the "... census is a drama at the very center of our political life."

In recent decades, the political dimension associated with the census appears to have been more pronounced in Germany than in any other country. In West Germany, rancorous debates about privacy rights led to a boycott of the census in 1983, and to the postponement of the census to 1987. A decade later, the government of reunified Germany insisted on a non-binding character of the European Community's guidelines for implementing censuses (Grohmann 2011), and became the only European Union member state that did not conduct a census at the turn of the last century. In 2008, the EU ratified a new and binding implementing regulation on the 2010/2011 census; this time with the support of Germany. The German government opted to conduct the 2011 census using a register-based approach, rather than relying on the "traditional" approach to census-taking that had been used up to that point. In light of Germany's experiences with the 1987 census, this move seemed reasonable. The transition to using a register-based approach is, however, a consequential step, especially because Germany - unlike the Scandinavian countries, which have long used register data for census purposes - does not have a central population register, and there are no serious plans to establish one. Furthermore, Germany still does not make use of a uniform identification number, such as a social security number, of the sort that the Scandinavian countries employ to link their registers. ${ }^{1}$ Additionally, under German law - as expressed, for example, in \$21 of the German Federal Statistics Act (Bundesstatistikgesetz) - there are strict conditions for the linking of the federal statistics registers (see BstatG (1987) and ZensG (2011)).

In this contribution, we discuss the 2011 register-based census from a demographic research point of view. After providing a historical classification of the 2011 census (section 1), we set out in section 2 to assess the accuracy of the population figures in the 2011 census. In section 3 we examine the systematic sources of error in the updated population estimates, and discuss the consequences of the census results for demographic indicators. In section 4 , we take a critical look at the benefits of the 2011 census for population research, and at the potential uses of the data that have yet to be fully explored.

1 While a uniform tax identification number was introduced in 2008 , this number has so far been of no relevance for the systematic linking of register data. There is, however, an indirect connection between this number and the census, because in the course of its introduction, the addresses in the registration offices (Einwohnermeldeämter) were corrected and completed. 


\section{The census in Germany: A historical classification}

\subsection{The development of the modern census in Germany up to 1939}

Together with church records, data from censuses have always been the main sources used in demographic analyses. It is important to note, however, that the modern census was not developed out of a genuine interest in understanding demographic or social processes. The history of statistical recordings of the population, as well as of the survey of specific structural characteristics, is directly linked to the emergence of public administrative bodies, and can thus hardly be separated from the interests of political actors. Initially, the surveys focused on the population size, the number of taxpayers, and the number of men fit for military service. It was not until later that data on the structure of households and on certain characteristics of household members - such as profession, educational level, marital status, or citizenship were collected (Gehrmann 2009; Grohmann 2000, 2011; Rothenbacher 1997).

Censuses have been conducted on the territory of present-day Germany since the Middle Ages. However, the first population counts took solely place in individual cities. Starting in the early $19^{\text {th }}$ century, systematic censuses for entire regions were conducted, albeit with differing objectives and regularities. Generally, the focus of these censuses was on counting the number of inhabitants at a given point in time based on their official place of residence (de jure); and, later, the focus shifted to the number of inhabitants who were actually present (de facto) (Gehrmann 2009). For many centuries, demographic events such as births, marriages, and deaths were captured mainly by the parishes of the Catholic Church. Over the course of the Protestant Reformation, the newly Protestant parishes introduced "Registers of Souls," (Seelenregister or Martinilisten), while the Catholic parishes started compiling "Status animarum" registers. The data in these registers, which were largely collected and maintained by members of the clergy, can still be used to partially reconstruct information on historic households and families. Some original documents of these enumerations have been preserved until today, albeit in fragmented forms (see, e.g., Baten/Szołtysek 2014).

Most of the early censuses in Germany were conducted at irregular intervals by cities. But following the Congress of Vienna and the establishment of the German Customs Union (Deutscher Zollverein), systematic, uniform, and regular population counts were introduced (Grohmann 2000; Zahn 1900). ${ }^{2}$ The enumerations were

2 The establishment of the Bundesmatrike/ in 1818 provided the stimuli for the uniform calculation of the militia costs (Landsturm). In 1834, Prussia, Bavaria, Hesse-Darmstadt, Hesse-Kassel, and Wurttemberg founded the German Customs Union (Deutscher Zollverein), and conducted enumerations every three years (Gehrmann 2009). The procedure was completed within four weeks when it was first introduced, and within three days from 1843 onward. It was not until 1858 that the enumerations were conducted on a single reference day. Records were collected of the custom accounting population (Zollabrechnungsbevölkerung), and these records were often combined with the survey results in the police registers or the tax lists. The counts were also partly coupled with counts of buildings and livestock, as well as with the results of a survey of individuals of military service age. 
considered necessary because the individual states that belonged to the Customs Union were expected to contribute to the costs of the coalition's military operations in proportion to their population size. The member states of the Customs Union thus had to conduct regular enumerations to determine their population numbers. The surveys also enabled government bureaucrats to generate lists of households that were used for imposing household charges, poor rates, and a wide range of taxes, including poll, property, trade, income, hearth, war and church taxes. Citizen or inhabitant lists were used to ensure that all inhabitants contributed to the support of community services, such as orphan or poor relief.

The establishment of the German Statistical Association (Verein für deutsche Statistik) in 1846 and of the Central Statistical Office (Statistisches Zentralbureau) in Frankfurt in 1848 represented first steps in the development of a Germany-wide system of official statistics with uniform standards. For example, the 1864 census was the first to introduce the household as a survey unit (Gehrmann 2009). In addition, the last census of the German Customs Union in 1867 is considered a model for all of the censuses that were subsequently conducted in Germany and other European countries. The 1867 census used household lists that included information on both the de facto population and the inhabitants who were not present on the record date. ${ }^{3}$

Following the separation of church and state responsibilities and the founding of the German Empire in 1871, the official censuses conducted in Germany had a uniform, systematic structure, and were obliged to follow uniform quality standards (Miche/ 1985). Meanwhile, the documentation of demographic events (e.g., births, deaths, and marriages) was no longer left to the churches, but was instead taken over by state institutions, which passed this information on to the statistical authorities. The office of official statistics was developed as an independent agency of the administration, and was expected to provide the data needed to perform a wide range of administrative tasks. After 1871, enumerations took place in regular intervals of four or five years in all regions of Germany. Starting in 1900, the length of the intervals between censuses was extended to 10 years (for an overview of the census in Germany, see Table A1 in the Appendix).

The First World War interrupted all enumerations in Germany. During the war years, only restricted censuses were conducted, mainly in order to organise the food supply for the population. The 1939 census (which was originally planned for 1938), represents a notorious chapter in the history of censuses (see Wietog 2001 for details). Most historians now agree that the 1939 census was not the main source used for the identification and deportation of Jews in Germany, as the survey data were processed relatively late in the deportation process; and that other sourc-

3 The oldest census documents that are entirely preserved today are those of the Grand Duchy of Mecklenburg-Schwerin (Großherzogliches Statistisches Amt 1898; Manke 2005; Scholz 2013). For the Grand Duchy of Mecklenburg-Schwerin, the original documents include handwritten questionnaires and household lists by municipality that were collected in the censuses of 1819 , 1867,1890 (partly), and 1900. These documents provide information on each head of household, such as name, age, sex, marital status, confession, and profession. 
es were available for identifying individuals of Jewish origin and belief. However, Ehmer (2013: 74) has suggested that the statistical office (Statistische Reichsamt) did rely on publications in which the number of remaining Jews in Germany was identified based on data from the 1939 census, and that refer to the "effectiveness of anti-Semitic persecution."

\subsection{Censuses in divided Germany}

In the immediate aftermath of World War II, the four occupying powers conducted a census of Germany (see Table A1 in the Appendix). This 1946 census was, however, the last uniform census carried out in Germany until 2011. From 1949 onward, the official statistics systems in the two parts of Germany went their separate ways and conducted separate censuses. Whereas West Germany introduced an administration and statistics system at the federal state (Bundes/and) level, the GDR continued to maintain a centralised statistics system (Fischer 1994; Oettel 2006; Statistisches Bundesamt 1999). In the GDR, the census data were collected on a decentralised basis, but were processed centrally by the Central Administration for Statistics (later the Statistisches Amt der DDR). In the mid-1970s, the GDR established a central population data repository based on the model used in the Scandinavian countries. This population register included all inhabitants, and was linked to the birth, death, and migration statistics. The 1981 census was the last census conducted in the GDR that used traditional methodologies. The population figure on the census reference day deviated only slightly from the corresponding figure drawn from updated population registers $(20,000$ individuals out of 16.7 million inhabitants). The last register counting of the central resident database (Einwohnerdatenspeicher) was carried out on October 3, 1990. The generated population figures were incorporated into the now joint federal population statistics for eastern Germany. ${ }^{4}$

Unlike the GDR, official statistics in the Federal Republic of Germany are organised in a decentralised manner. The Statistical Offices of the federal states collect the data and deliver them to the Federal Statistical Office (Statistisches Bundes$a m t$ ) that combines the information into a unified statistics. Until today, Germany does not have a central population register. ${ }^{5}$ The population figures for Germany as a whole are based on censuses and updated population estimates. However, the controversies in the run-up to the 1987 census marked a sharp turning point in approaches to census-taking in Germany. The debate over the census had constitutional consequences, not just because of the approval of the so-called "Census Act" (Grohmann 2000). Germany did not take part in the EU-wide 2001 census, largely as

4 Linking the data of the GDR's resident database (population register) and the FRG's updated population estimates was accomplished largely without difficulties, since the two datasets were relatively comparable. For example, the criteria for including current residents and foreign military personnel were the same in both parts of Germany.

5

Although a discussion on establishing a central population register was initiated by Wolfgang Schäuble (CDU) in 2008 (Der Spiege/ 2008), the topic has not been seriously raised since then. 
a consequence of the boycott of the previous census and the flood of census-related lawsuits that were filed starting in 1983 (Eppmann 2004). Nevertheless, debates over whether a register-based census should be conducted began in the wake of the 1987 census (Bierau 2001; Eppmann 2004; Eppmann/Schäfer 2006).

\subsection{Census}

In 2011, or 20 years after the last enumeration, Germany finally conducted a nationwide census. For the first time, the country opted for a register-based approach. In order to generate the population figures, data from the decentralised municipal population registers were used. Overcoverages (outdated files) and undercoverages (missing files) in the population registers were the most central problems that arose in using this approach. These registers contained many sources of errors, including the multiple registrations of individuals with multiple residences, and errors related to migration. Since 2000, the local population registration offices have been automatically comparing all of the records on movements within Germany. Furthermore, individuals are legally required to notify the responsible registration offices upon moving from one residence in Germany to another. However, unlike internal migration, migration abroad is not subject to systematic official controls (Bucher 2014: 150). ${ }^{6}$ In addition, the quality of the register data can vary across individual registration offices. For example, it has been shown that the differences between the updated population estimates based on data from the local population registers of Rhineland-Palatinate differ little from the new census data. This consistency is largely attributable to the introduction of an internal registration procedure for internal migration in Rhineland-Palatinate as early as in the 1970s (Bucher 2014: 150). Moreover, Rhineland-Palatinate keeps and maintains a population register at the state level. ${ }^{7}$

Attempts were made to correct the population figures that were transmitted from the local registration offices to the statistical offices with the help of a complex, multi-stage correction procedure (Berg 2011; Dieh/ 2012; Miche/ 2004). ${ }^{8}$ Furthermore, in order to check the quality of the population registers, an additional household sample was drawn. However, the household sample was used to verify the quality of the register data only for municipalities with more than 10,000 inhabitants. The reasoning behind this decision was that the results of the census test showed that there were more irregularities in the population registers of big

6 The procedure was gradually modified in 2000 . Since around 2004 , the procedure for automatically matching the registrations and deregistrations has been applied throughout the country.

7 The other federal states that maintain central population registers are the city states of Berlin, Hamburg, and Bremen; as well as the federal state of Thuringia.

8 However, because of legal restrictions (the so-called Rückspie/verbot), the corrections made by the Federal Statistical Office were not transferred back to the population registers of the municipalities. This failure to transfer the corrections may have resulted in a gap between the census population figures and the figures of the population registers on the day of the census (Kaus/Mundil-Schwarz 2015). 
municipalities than in those of smaller ones (Statistisches Bundesamt 2015: 27). For smaller municipalities, the data were corrected only if certain irregularities were detected.

It is generally assumed that, due to the errors in the updated population estimates, the old-age mortality figures and the mortality and fertility rates reported for the foreign population were especially distorted (Kibele et al. 2008). Accordingly, the new population figures of the 2011 register-based census were eagerly awaited. This anticipation was, however, clouded by the long period of time that passed between the collection and the publication of the data. While the reference date was May 9, 2011, the first (partly) preliminary and highly aggregated results were not available until May 2013. Moreover, the initial data by age and sex were not published until January 2014, and the final data of the updated population estimates and the 2011 census were not published until April 2015. Thus, four years passed between the recording and the publication of the final results. Although it was well known that the data that were used included a net deviation in the population figures of 1.5 million on the reference day, during these four years the calculations still had to be based on the updated data of the 1987 census, because the new data were subject to legal and content-related reservations (Bucher 2014: 149). Similarly, the Federal Statistical Office had to wait a very long time for the release of the final census data on age, sex, and citizenship needed to calculate the 13th coordinated population projection and the life tables 2010/12. International demographic datasets, such as the Human Fertility Database (HFD) and the Human Mortality Database (HMD), also used until recently the "old" updated estimation results. ${ }^{9}$

\section{How accurate are the population figures of the 2011 census?}

According to the current enumeration, the officially confirmed total population of the Federal Republic of Germany on the reference date of May 9, 2011, was 80,219,695 inhabitants (Statistisches Bundesamt 2014c). Although this figure is seemingly precise, it is important to note that, like similar figures arrived at in the censuses of other countries (Hillygus et al. 2000: 17), it is the result of a complex estimation process. ${ }^{10}$ Whereas from a research point of view it would seem preferable to conduct sensitivity analyses in order to check the robustness of the estimation, given

9 In the HFD (http://www.humanfertility.org/) and the HMD (http://www.mortality.org/), the demographic data of different countries are prepared in a comparable manner and are made available to the scientific community and the interested public for download. Because of the high demands on the comparability of data - not only between countries, but also over time researchers have used a back calculation to balance the distortions in the databases that arise from the errors in the updated estimates in Germany. Due to the relatively late publication of the new census results, the back calculation could not be applied until recently.

10 A census figure is an estimation of the population at a given point in time. Its accuracy depends in part on the time lag between the occurrence of demographic events (birth, death, migration) and their registration. In some cases, there is a time lag of up to six months between the occurrence and the complete registration of an event (Hannemann/Scholz 2009). 
the census' political dimension it is clear that an exact, officially confirmed, and, preferably, incontestable population figure is needed. In spite of (or presumably because of) the complex and logistically challenging procedures used to generate these results, and their apparent accuracy, the census results are being questioned, particularly by those municipalities that feel disadvantaged by the outcomes. The current census is vulnerable to criticism in particular because of its systematically different treatment of small and large municipalities (Christensen et al. 2015; Rendtel 2015; Statistisches Bundesamt 2015).

Demographic researchers are faced with the question of to what extent the 2011 census presents a precise picture of the actual population figures. Although the procedures used to generate the data have been described in various publications of the Federal Statistical Office (Statistische Ämter des Bundes und der Länder 2004; Statistisches Bundesamt 2015), and were discussed in advance with representatives of the scientific community in a number of committees, such as the Census Commission and its subgroups, the options researchers have to verify the census data are extremely limited. Due to the complexity of the procedures applied and to the fact that, in the end, scientists can only analyse the final figures, not the procedures used to generate these figures, validating the census is akin to engaging in detective work (Rendte/ 2015).

In the following, we attempt to "elicit" the population figures of the 2011 census. Due to the lack of reliable external data, a comprehensive validation of the data is not possible (see, however, section 4.2 for the external validation of the 2011 census estimates and the updated estimates, exemplified using the elderly population). Moreover, it is not possible to conduct sensitivity analyses, since this would require us to have access to the population register and the household survey data that were used for generating the population figures. The Federal Statistical Office has granted researchers access to the household survey for scientific analyses, and is also planning to make the census data available as individual-level datasets. However, because all the auxiliary characteristics were deleted at the earliest possible point in time on the grounds of data protection, reconstructing the calculation of the population figures is impossible, even if researchers have the individual-level data of the census at their disposal.

Thus, our only option is to use the results of the updated population estimates based on the 1987 census to evaluate the 2011 census results. Given our lack of better alternatives, we will follow the approach of Bucher (2014), Rendtel (2015), Christensen et al. (2015) and of Kaus/Mundil-Schwarz (2015), who compared the population figures of the 2011 census with the updated estimates of the 1987 census. We do not have a valid external measure for estimating the quality of either dataset. Nonetheless, the systematic deviations allow us to draw conclusions regarding the factors that distort the results. The 2011 census figures for May 9, 2011, as well as the data of the updated estimates (by the end of the respective calendar year) serve as databases for this investigation (Statistisches Bundesamt 2013b, 2014a/b).

In the framework of the 2011 census, an additional survey that included 10 percent of the households in Germany has been drawn in order to gather additional information not included in the registers. This sample is also used to identify errors 
in the population registers for larger municipalities. Past evaluations have generally shown that the census results for smaller municipalities, for which there have been fewer corrections, deviate less from the updated estimates than those of bigger municipalities, which show higher deviations on average (Bucher 2014; Christensen et al. 2015). In Figure 1 we replicate this result in the form of a scatterplot. Every dot in the figure corresponds to one municipality, a total of around 11,000 municipalities are represented in the figure. The ordinate depicts the difference between the 2011 census data and the "old" updated results. The abscissa covers the population figure of the individual municipality. The figure shows that the relative variation is significantly higher for smaller than for larger municipalities. It also shows that the variation decreases rapidly at a population figure of 10,000 inhabitants.

Fig. 1: Relative difference (in \%) between the updated estimates of the 1987 census and the 2011 census results, by size of municipalities on May 9 , 2011

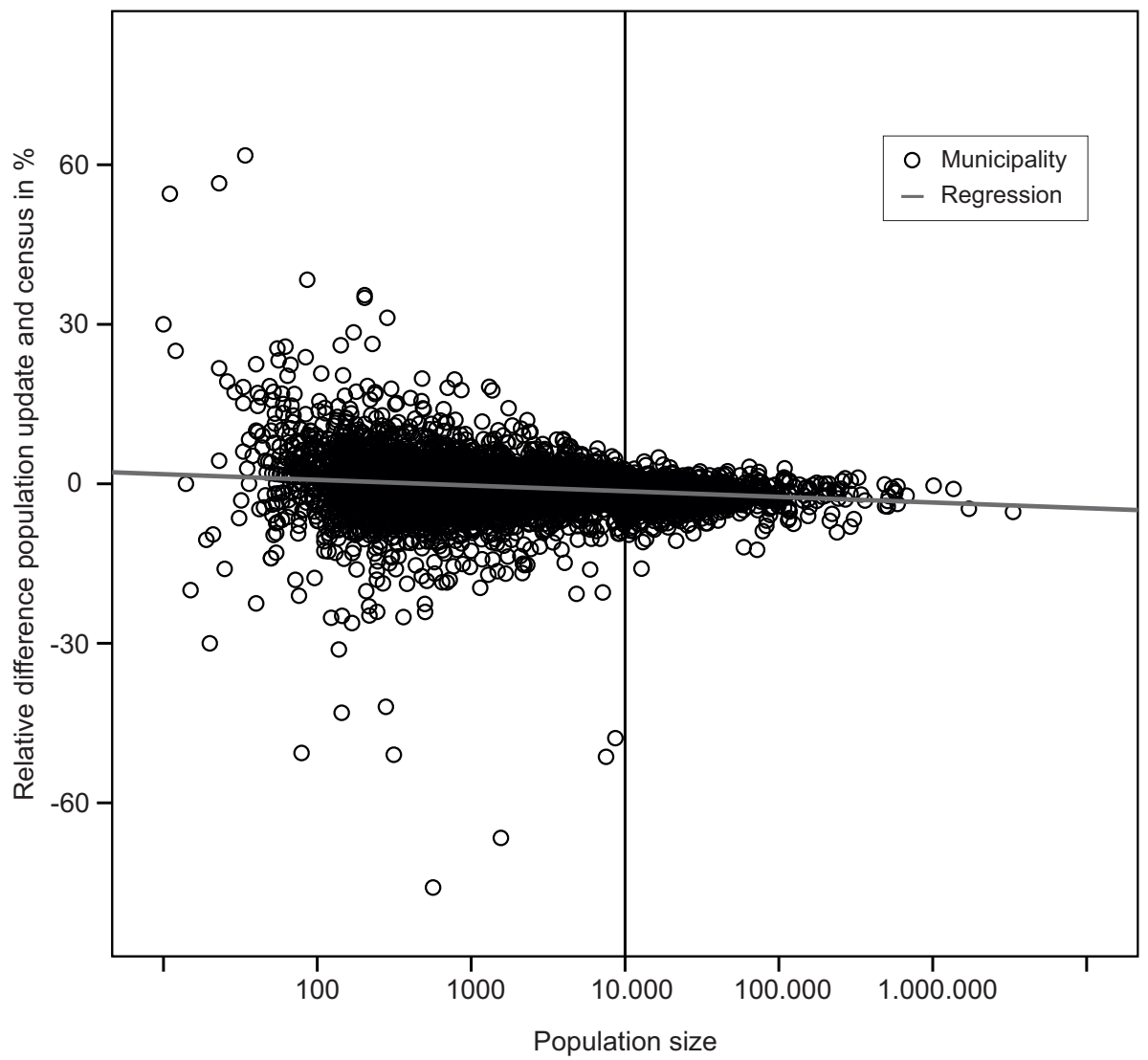

Source: Statistisches Bundesamt 2014a/b 
Figure 2 systematically compares the degree of deviation between the 2011 census and the updated estimates for small and large municipalities. The abscissa shows the relative difference between the census and the updated estimates. On the ordinate, the number of municipalities is presented. The figure shows considerably less deviation in large than in small municipalities. On average, the relative difference between the updated estimates and the census data is 2.27 percent for large municipalities, compared to 0.48 percent for small municipalities. ${ }^{11}$ This result is of political relevance because the system of fiscal equalisation between the federal states depends on the numbers of inhabitants, and the distribution of small and large municipalities differs across the federal states. For example, in Rhineland Palatinate, the number of small municipalities is relatively large; whereas in North

Fig. 2: Number of municipalities (ordinate) by relative difference in $\%$ between 2011 census and updated estimates of 1987 census (abscissa), by small municipalities (fewer than 10,000 inhabitants) and big municipalities $(10,000$ or more inhabitants)

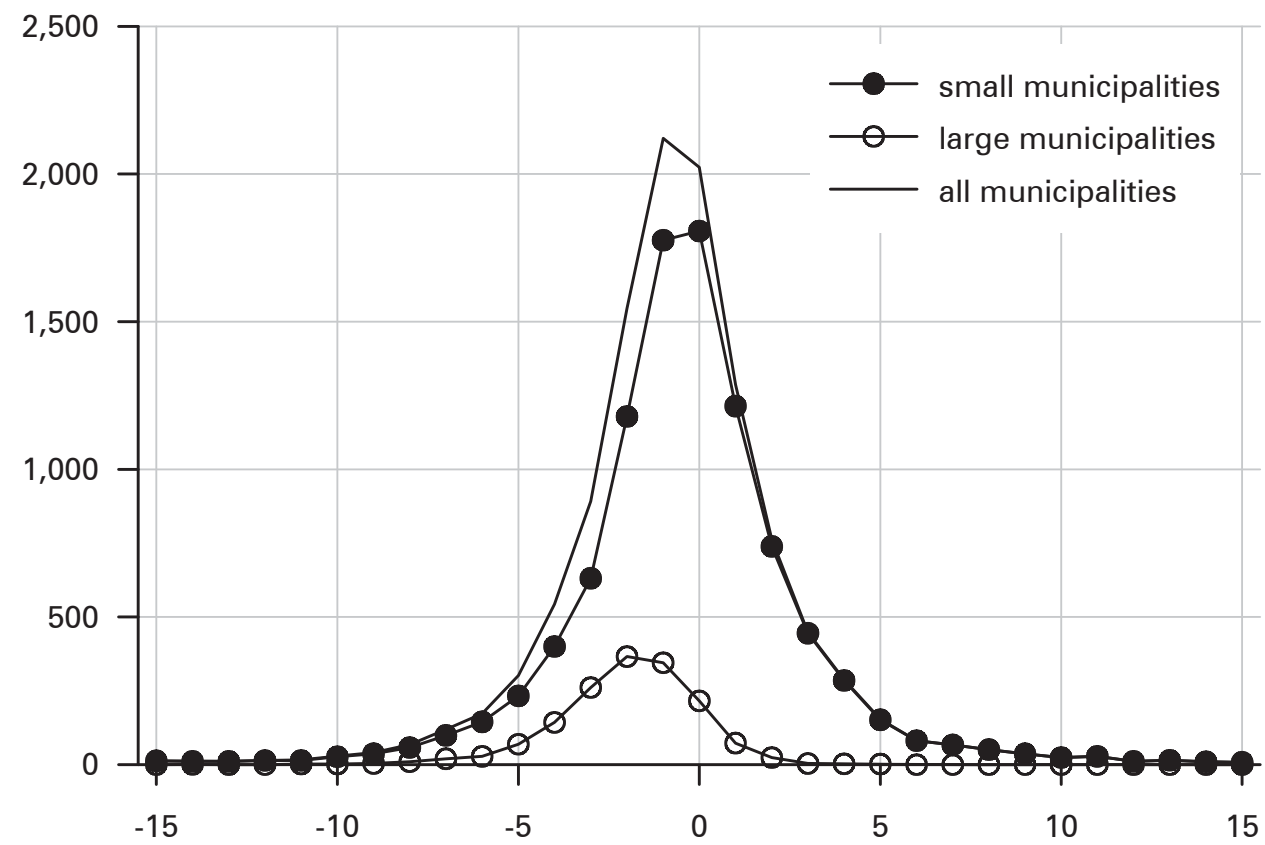

Note: Municipalities were designated as big or small according to their number of inhabitants in the updated estimates.

Source: Statistisches Bundesamt 2013b

11 The mean values were calculated by weighing the population figures of the individual municipality based on the 2011 census results. 
Rhine Westphalia, the number of municipalities with fewer than 10,000 inhabitants is relatively small (see Fig. A1 in the Appendix for a representation of the differences across the federal states). Because the distribution of large and small communities differs across the federal states, the population figures for the federal states in which a relatively large share of the municipalities are small may have required fewer corrections (see Christensen et al. 2015; Rendte/ 2015 for further details). The significantly lower degree of variation among municipalities with fewer than 10,000 inhabitants suggests that the method had a systematic influence on the population figures. At this point, no final statement can be made regarding the question of whether the different degrees of deviation between the updated estimates and the census results depending on municipality size are solely attributable to the method applied, or whether they result from the varying quality of the updated estimates which might be more accurate in the smaller municipalities. ${ }^{12}$ At the same time, however, it can be assumed that the total population in Germany was somewhat overestimated by the applied method, since the population figures of smaller municipalities have not been adjusted downward. ${ }^{13}$

\section{$4 \quad$ Quality of the updated population estimates}

\subsection{Differences between the census results and the updated estimates by age, sex, and nationality}

Although the 2011 census only provides an estimated value of the population figures for the year 2011, which might include a slight overestimation of the population figures of small municipalities, this value is still the only criterion we can use to evaluate the quality of the updated estimates. In the past, it was not possible to estimate the old-age mortality figures on the basis of the updated population estimates, because the updated population figures were known to be significantly distorted in old age (Kibele et al. 2008). One of the main reasons for the overestimation of the population figures are relocations abroad, which are often not registered, and are therefore not included in either the migration statistics or the updated population estimates.

12 The age structure and the proportion of foreigners relative to the total population are central factors that influence the quality of the population registers in the municipalities. Since the share of the foreign population is, on average, lower in small municipalities than in large ones, the registers in small municipalities are less affected by the undocumented relocations of foreigners. Furthermore, members of the highly mobile age group 20-39 are less heavily represented in small municipalities than in large municipalities (see Fig. A3 in the Appendix). This factor might also influence the quality of the registers in small communities.

13 However, non-registered persons were not systematically searched for, which might result in an underestimation. Yet to our knowledge, there are no indicators that reflect the extent of a possible underestimation due to individuals not being registered. A further reason why the population figures might be underestimated in the census is that some relocations and births might not be registered (see also footnote 10). 
Against this background, Figures $3 \mathrm{a}$ and $3 \mathrm{~b}$ present the differences between the census and the updated estimates by year of birth and by sex - for foreigners and for Germans. The abscissa shows the deviations between the updated estimates and census data for men, with the ordinate showing the deviations for women. Each dot in the figure represents one birth cohort. The closer the values are to the origin of the coordinate system, the better the updated estimates and the census results match. Positive values indicate that the population figures were corrected downward by the 2011 census. Negative values, accordingly, indicate an upward correction. The values on the diagonal indicate that the distortions were the same for women and men (see also Fig. A2 in the Appendix for a two-dimensional image).

Looking first at the pattern for Germans (Fig. 3a), it is noteworthy that for the younger cohorts the values were corrected upward. For example, the 2009 cohort was corrected slightly upward (by 0.5 percent) by the census data. Since the 2009 cohort was two years old at the time of the census, one would expect that the errors in the updated estimates would be rather small. Presumably, the negative deviation for the younger cohorts is attributable to the fact that the characteristic "citizenship" created ambiguities for individuals with dual citizenship. Furthermore, Figure $3 a$ indicates that the deviation is more pronounced among men, and does not show a symmetric pattern in the coordinate system. There are various reasons for the differences between the sexes. First, the non-proportional change in the deviation of the census results suggests that there were sex-specific differences in migration behaviour. Second, women and men might have differed in the extent to which they followed the guidelines for registering and deregistering. Finally, it cannot be ruled out that when the register was being adjusted, different corrections were made according to sex.

Figure $3 \mathrm{~b}$ presents the results for the foreign population. It is important to keep in mind that an axis with a different range was used for the foreign population than for the German population (Fig. 3a), because the deviation between the census results and the updated estimates was considerably more significant for foreigners than for Germans. For foreigners, the census data and the estimates differ considerably, especially at older ages. By contrast, we do not find such a pronounced imbalance among the German population. A higher degree of deviation is found for men than for women among both the German and the foreign population. For example, for foreign men of the 1950 cohort, there is a difference of 12 percent between the updated estimates and the 2011 census results. For foreign men of the 1940 birth cohort, the difference is 17 percent, and for foreign men of the 1930 cohort, the difference is nearly 50 percent. For very old foreign men, who were born in 1921 or earlier, the difference between the updated estimates and the 2011 census results is more than 600 percent; a value that is not included in the figure.

In conclusion, our findings suggest that the new census results mainly corrected the population figures for the elderly foreign population. Furthermore, the values for men changed more substantially than the values for women. Thus, the relevance of the census results differs considerably from the point of view of a fertility researcher compared to the perspective of a mortality researcher. When calculating fertility indicators, only the population figures of women aged 15 to 49 are used. As 
Fig. 3a: Representation of the relative deviation of the 2011 census from the updated estimates based on the 1987 census for men and women, by cohorts for Germans

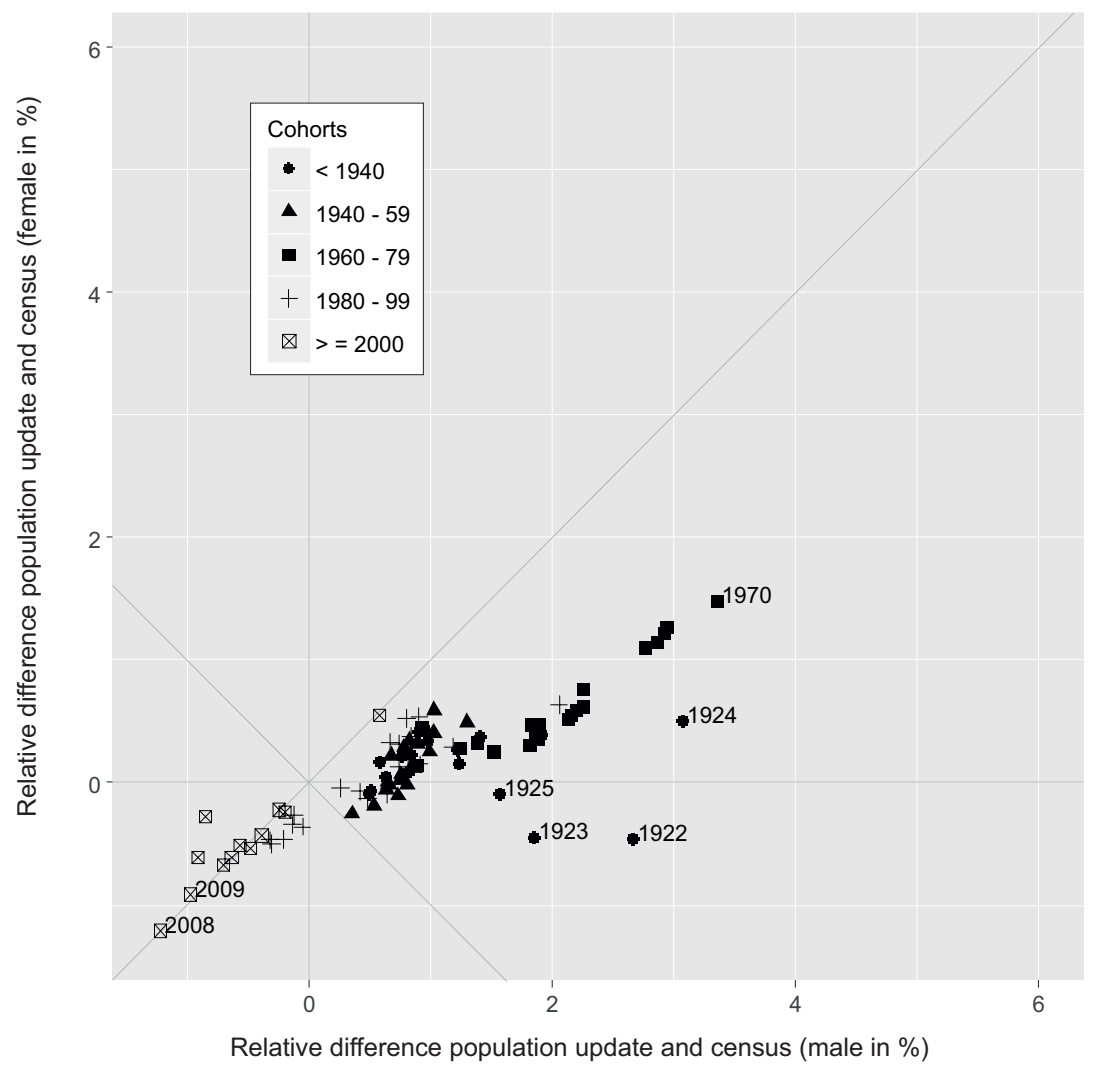

Source: Statistisches Bundesamt 2014a/b.

the discrepancies between the census results and the updated estimates are smallest for this group, the influence of the new census data on the fertility indicators is likely to be small. The fertility figures by citizenship, which were calculated based on the updated estimates, are considerably more distorted (see Pötzsch 2016; zur Nieden/Sommer 2016). In mortality research, the new census results provide a significant correction of the old-age mortality rate. Moreover, the proportions of people in long-term care are likely to change considerably based on the census data (see Table A2 in the Appendix). Since the Federal Statistical Office is not planning any back calculations for correcting the population figures by age, we have to accept leaps in the time series of the demographic indicators, which differ according to sex and, especially, according to citizenship. 
Fig. 3b: Representation of the relative deviation of the 2011 census from the updated estimates based on the 1987 census for men and women, by cohorts for foreigners

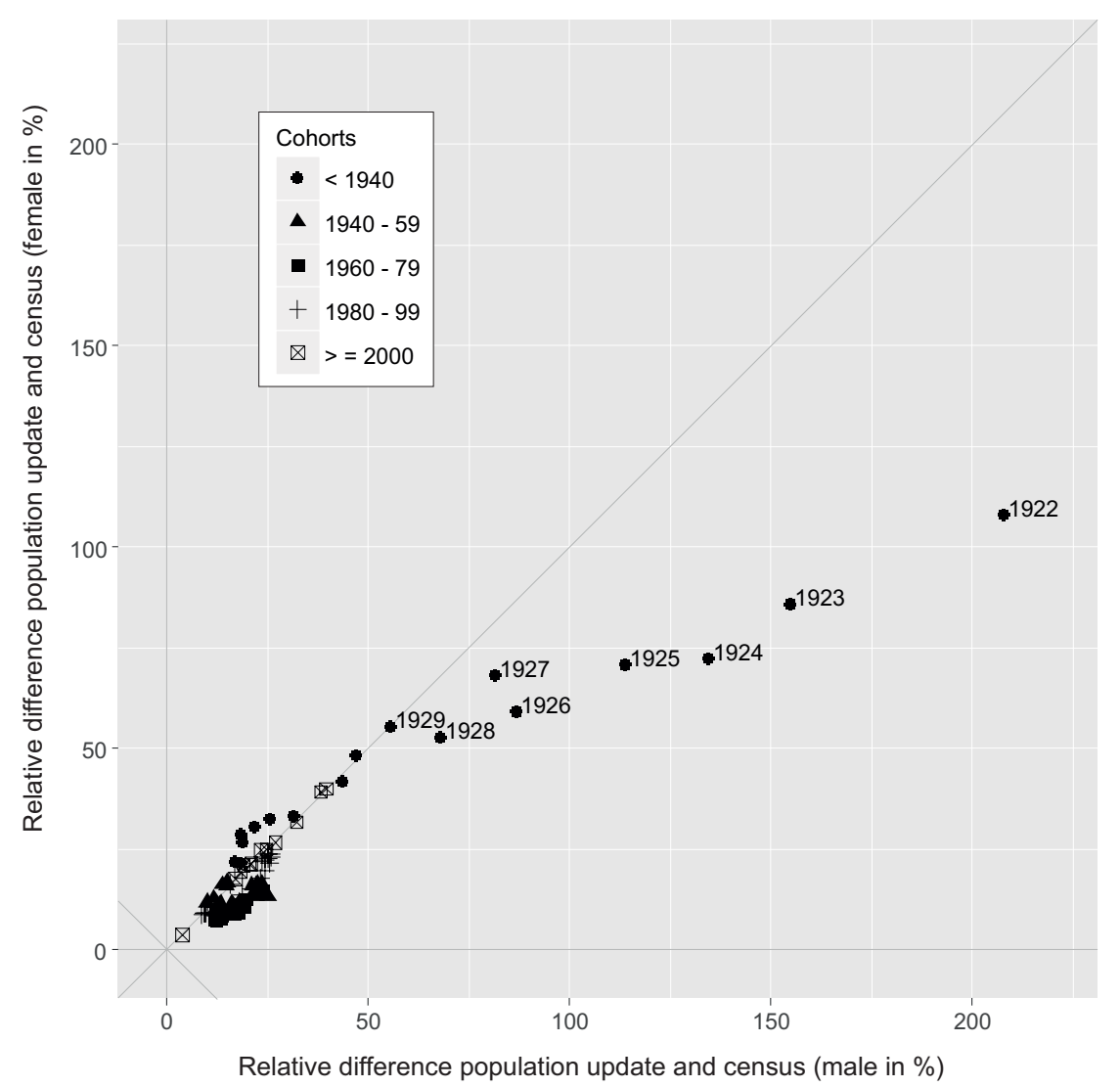

Source: Statistisches Bundesamt 2014a/b.

\subsection{External validation of the 2011 census and the updated estimates exemplified using the old-age population}

In general, information about the population in Germany is provided only on the basis of the census and the updated estimates. There are, however, indirect procedures that use alternative data sources to generate population figures. These figures can lend plausibility to the quality of both the census and the updated estimates. Among these sources are the estimates of deaths in older age groups. Since the number of deaths by age can be derived from the death statistics in a relatively reliable manner, the number of individuals by birth cohort and by sex who were alive in previous years can be indirectly derived from their ages at death. This is an indirect method based on the assumption that migrations abroad are very rare 
among the aged population. However, because this method can only be applied to those cohorts whose members are all deceased, it has to be restricted to very old ages. Despite these limitations, sensitivity analyses for different countries have demonstrated that this method provides qualitatively better population figures than updated estimates (Jdanov et al. 2005).

Figure 4 illustrates the difference between the updated estimates and the number of individuals aged 90 or older calculated based on the death statistics. The census values are marked with a cross. As we can see in the figure, the value for the census and the value for the population based on the death statistics are almost identical. This provides evidence that the quality of the census results for very old age groups is good. Conversely, this finding confirms the imbalance of the "old" updated estimates. At age 90 , the deviation between the updated estimates and the "actual" values in 2008 is more than 30 percent.

Figure 4 also presents the differences between the updated estimates and the population estimates based on the death statistics for previous years. At the reference date of each population census there are only minor discrepancies which tend to increase with the time that has passed since the preceding census. Among men, for example, the differences rise from 0.6 percent in the 1987 census to roughly 25 percent in 2011. However, there is also a very uneven development over time, with the differences decreasing instantly in 2008. This erratic development can probably be explained by the adjustments of the registers. First, the residents' registers were adjusted between 2007 and 2010 in connection with the introduction of the tax identification number (Kaus/Mundil-Schwarz 2015). Second, in the course of the census tests between 2001 and 2004, adjustments to the registers were conducted which are probably linked to the adjustment of the central register of foreigners from 2001 to 2003. Presumably, most of the discovered misrepresentations within the registers were cases of individuals no longer living in Germany. These individuals were deleted from the registers by marking them as "relocation unknown" (for Germans) and "relocation abroad" (for foreigners).

In order to understand why these adjustments influenced the updated estimates of the census, it is essential to be aware that the national migration statistics in Germany are based on the data from the population registers of the local municipalities. If the municipalities record an increase in emigration, this increase will eventually show up in the updated estimates of the census. ${ }^{14}$ Problems with data from these population registers can arise for a number of reasons. First, the registers were

$\overline{14}$ In the description of the migration statistics, the following passage appears: "It should be taken into account for 2008 and 2009 that a considerable amount of correction work was carried out in the population registers in these two years because of the nationwide introduction of the personal tax identification number in 2008 , and that this led to many people being removed from the registers by the authorities. Since it is impossible to statistically quantify the extent of these corrections from the reports filed by the registration authorities, the actual extent of emigration in 2008 and 2009, as well as the developments in comparison to the previous years, remains unclear" (Bundesamt für Migration und Flüchtlinge 2015: 13) (for English version, see https:// www.bamf.de/SharedDocs/Anlagen/EN/Downloads/Infothek/Forschung/Studien/migrationsbericht-2013-zentrale-ergebnisse.pdf?__blob=publicationFile). 
Fig. 4: Relative difference at age 90 or older (in \%) between the updated population estimates and the population calculated from the death rate in relation to the population update

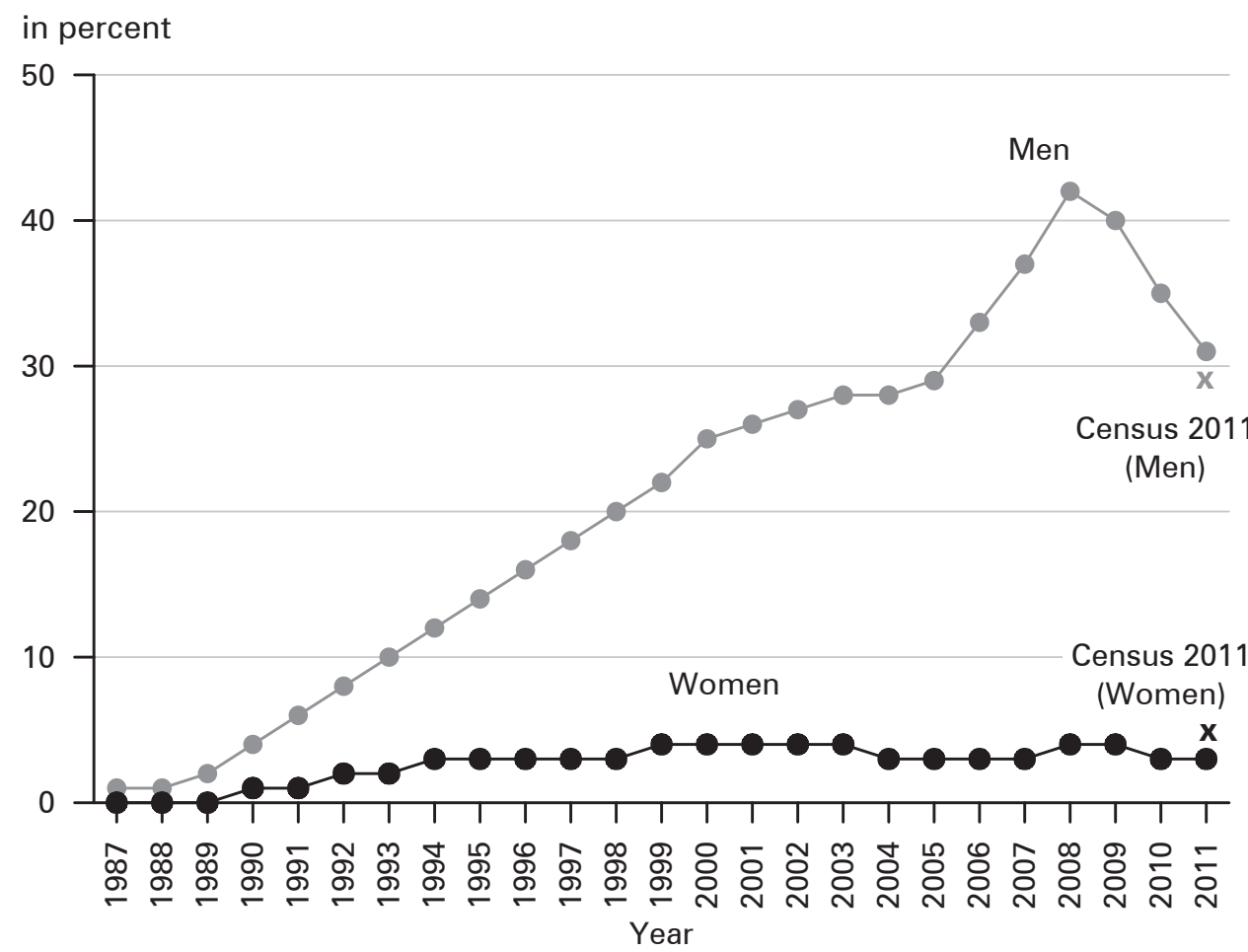

Source: Own calculations, based on Human Mortality Database (http://www.mortality.org/)

corrected at a certain point in time after the year 2001, even though the flaws in the register data were largely caused by non-recorded migrations that occurred in the 1990s. Second, it is regrettable that the corrections were not marked as such, as it is impossible to reconstruct for the years 2008/2009 whether net immigration in Germany was indeed negative, or whether this result was "produced" by the corrections only. Because the migration statistics are also included in the updated estimates, the correction indirectly changes the population figures of the updated estimates, as well - and thus changes the basis for calculating demographic indicators.

\section{Conclusion}

As in other countries, the census in Germany fulfills various functions. For public administrative agencies, the census and the updated population estimates are the basis for planning a wide range of development projects and the provision of services, including those related to local infrastructure, housing and transport in- 
frastructure, traffic flows, medical and care infrastructure, schools, the promotion of education and culture, social benefits, and energy supply (see ZensG 2011 § 1). ${ }^{15}$ Census population figures are also central to demographic research, as mortality and fertility figures are calculated based on these figures. Furthermore, the census is of major importance for social science surveys. The number of inhabitants by municipality, birth year, and sex are of immediate relevance for the drawing of samples from the registration offices. The census also provides the sample plan on which the structure of the enumeration districts for the microcensus are based. The results of the microcensus are, in turn, used to generate the "post-stratification weights" for the social science surveys.

Is the census significant for demographic and social science research for reasons that go beyond those described above? Because the census data include a large number of cases, the results could be used to conduct regionalised scientific analyses. However, given that up to today (e.g., five years after the census) it is not yet clear whether - and, if so, in what ways - regionalised individual census data will be provided, the census data might become less and less attractive for scientific research over time. This observation also applies to the data of the additional household survey, which have also only recently been made available for scientific microanalyses. More recent microcensus results are now available that have a similar - or in some cases a greater - potential for addressing family demographic issues relative to the household survey of the census. The (final) population figures by age and sex, which are particularly relevant for generating demographic indicators, were published with a four-year delay. By comparison, in Sweden, where the population registers have been systematically developed, the final population data by age and sex are published within one year.

One argument that was made for conducting a register-based census was that it would be less expensive and more effective than using traditional census-taking methodologies, because the necessary data were already available in the registers (Bierau 2001: 335; Eppmann 2004). However, the complex procedures that were needed to link the different registers call this assertion into question. The lack of transparency and verifiability of the census results are certainly attributable in large part to the specific legal framework in Germany. However, the question arises as to whether the ability to link the registers has been overestimated. Even in Norway, where the household register has been built up systematically over a long period of time, the 2011 census was the first one for which household register data have been used (Zhang/Hendriks 2012). It is indeed surprising that Germany, which has no experience with household registers, chose in its first attempt at conducting a register-based census to generate the household information from the register data using a highly complex procedure (Vorndran 2004). In the end, the opportunities offered by the register-based 2011 census have not been used to build up and

${ }^{15}$ Federal Act on the register-based 2011 census (Zensusgesetz 2011, ZensG 2011) as published on July 8, 2009. 
maintain over the long term a household register, a population register (as in Switzerland), or an administrative register.

In addition to its relevance for social policy, demography, and social science research, the census results are also significant from a political point of view, because the population figures calculated from these results and the subsequent updated estimates serve as the basis for the financial equalisation scheme between municipalities and federal states, as well as for the configuration of the constituencies for national and federal elections. As an undesirable side effect of the census' "dual nature," criticism of the census - even if it is based on scientific grounds alone - is a sensitive issue. The census is always vulnerable to being instrumentalised for "political purposes" by those who feel they are disadvantaged by its results. Because the validity of population figures is a political issue, it can be difficult to ensure that the debate about how the population figures are generated remains factual and scientific. The vehement complaints made by some politicians about the census corrections of the population figures (see, e.g., Rennefanz/Zylka 2013 for Berlin) are still surprising, given that in the past the serious shortcomings of the updated estimates were tacitly accepted. While politicians have been challenging the population figures of the 2011 census (Statistisches Bundesamt 2016), they have been less eager to engage in a discussion about how the population registers and the updated population estimates can be improved. The problems that distorted the population figures in the updated estimates have yet to be resolved. We therefore expect that systematic errors will occur again in the future developing in line with the time lag since the last census.

\section{Acknowledgements}

We thank Lena Klein for the translation of this article into English. We wish to thank Harald Utne (Senior Adviser Population Statistics, Statistics Norway) for his valuable advice concerning the household-generating procedure in the Norwegian census, as well as Gunnar Andersson (Stockholm University, Demography Unit) for providing information on the Swedish registers. Many thanks to Bernhard SchimplNeimanns for providing information on the German microcensus. We would like to thank Rainer Walke (Max Planck Institute for Demographic Research) very sincerely for his support in creating Figures $3 a$ and $3 b$. Last but not least, we would like to thank the reviewers and the editors of CPoS for their valuable comments on an earlier version of this manuscript. All remaining errors are ours.

\section{References}

Baten, Jörg; Szołtysek, Mikolaj 2014: A golden age before serfdom? The human capital of Central-Eastern and Eastern Europe in the 17th-19th centuries. MPIDR Working Paper 2014-18 [http://www.demogr.mpg.de/papers/working/wp-2014-008.pdf, 25.07.2016].

BStatG 1987 (Bundesstatistikgesetz BStatG vom 22. Januar 1987): [https://www.destatis.de/DE/Methoden/Rechtsgrundlagen/Statistikbereiche/Inhalte/010_BStatG.pdf? blob= publicationFile, 25.07.2016]. 
Berg, Andreas; Bihler, Wolf 2011: Das Hochrechnungsverfahren zur Ermittlung der Einwohnerzahl im Zensus 2011. In: Wirtschaft und Statistik 2011/3: 230-235 [https://www. destatis.de/DE/Publikationen/WirtschaftStatistik/Zensus/HochrechnungsverfahrenEinwohnerzahl_42014.pdf?_blob=publicationFile, 25.07.2016].

Bierau, Dieter 2001: Neue Methode der Volkszählung. Der Test eines registergestützten Zensus. In: Wirtschaft und Statistik 2001/5: 333-341 [https://www.destatis.de/DE/ Publikationen/WirtschaftStatistik/Zensus/NeueMethodeVolkszaehlung_52001.pdf? blob= publicationFile, 25.07.2016].

Bucher, Hansjörg 2014: Der Zensus 2011 und seine Auswirkungen auf demographische Eckwerte. In: Europa Regional 20: 147-159 [http://nbn-resolving.de/urn:nbn:de:0168ssoar-424095, 25.07.2016].

Bundesamt für Migration und Flüchtlinge 2015: Migrationsbericht 2013. Nürnberg: BMF [https://www.bamf.de/SharedDocs/Anlagen/DE/Publikationen/Migrationsberichte/ migrationsbericht-2013. pdf; jsessionid =652E955CA8155AC5E64D85329E541331.1 cid359?__blob=publicationFile, 25.97.2016].

Christensen, Björn et al. 2015: Everything counts! Warum die kleinen Gemeinden die Gewinner der Zensuserhebung 2011 sind. In: Wirtschafts- und Sozialstatistisches Archiv 9,3: 215-232 [doi: 10.1007/s11943-015-0173-x].

Der Spiege/ 2008: Einwohnerdaten: Schäuble plant zentrales Bundesmelderegister. (Der Spiegel vom 27.06.2008).

Diehl, Eva-Maria 2012: Methoden der Mehrfachfallprüfung im Zensus 2011. In: Wirtschaft und Statistik 2012/4: 473-484 [https://www.zensus2011.de/SharedDocs/Downloads/DE/Publikationen/Aufsaetze_Archiv/2012_06_Destatis_Methoden_der_Mehrfachfallpruefung_im_Zensus_2011.p̄df?_blob=publicationFile $\bar{\varepsilon} v=14,25 . \overline{07} .20 \overline{16}]$.

Ehmer, Josef 2013: Bevölkerungsgeschichte und Historische Demographie 1800-2010. 2. um einen Nachtrag erweitere Auflage. München: Oldenbourg Wissenschaftsverlag.

Eppmann, Helmut 2004: Von der Volkszählung 1987 zum registergestützten Zensus 2010? In: Statistische Analysen und Studien NRW 17: 3-9 [https://www.zensus2011.de/SharedDocs/Downloads/DE/Publikationen/Aufsaetze_Archiv/2004_NRW_Von_der_Volkszaehlung_zum_registergestuetzten_Zensus2010.pdf?__blob $=$ publicatioñ File $\bar{\varepsilon} v=11$, 25.07.2016]

Eppmann, Helmut; Schäfer, Josef 2006: Der Weg zu einem ersten registergestützten Zensus in Deutschland im Jahre 2011. In: Statistische Analysen und Studien NRW 27: 3-15 [https://www.zensus2011.de/SharedDocs/Downloads/DE/Publikationen/Aufsaetze_Archiv/2006_NRW_Der_Weg_zum_ersten_registergestuetzten_Zensus_in_ Deutschland.pdf?_blob= publicationFile\&v=9, 25.07.2016].

Fischer, Peter 1994: Entwicklung der amtlichen Statistik in der sowjetischen Besatzungszone Deutschlands und der DDR - 1945 bis 1990. In: Jahrbücher für Nationalökonomie und Statistik 213: 597-617.

Gehrmann, Rolf 2009: German Census-Taking Before 1871. MPIDR Working Paper 2009023 [http://www.demogr.mpg.de/papers/working/wp-2009-023.pdf, 25.07.2016].

Grohmann, Heinz 2000: Geschichte und Zukunft der Volkszählung in Deutschland. In: Berliner Statistik (Statistische Monatsschrift) 12: 216-223.

Grohmann, Heinz 2011: Volkszählung und Mikrozensus. In: Grohmann, Heinz; Krämer, Walter; Steger, Almut (Eds.): Statistik in Deutschland. Berlin/Heidelberg: Springer: 207-221 [doi: 10.1007/978-3-642-15635-9_17].

Großherzogliches Statistisches Amt 1898 (Ed.): Statistisches Handbuch für das Großherzogthum Mecklenburg-Schwerin. Schwerin. 
Hannemann, Anke; Scholz, Rembrandt D. 2009: The mortality of non-Germans in Germany: A comparison of results estimated from the Official Statistics and the Central Register of Foreigners. Rostock Center Discussion Paper 26, Rostock Center for the Study of Demographic Change [http://www.rostockerzentrum.de/content/publikationen/rz_diskussionpapier_26.pdf, 25.07.2016].

Hillygus, D. Sunshine et al. 2000: The Hard Count. The Political and Social Challenges of Census Mobilization. New York: Sage.

Jdanov, Dmitri A.; Scholz, Rembrandt D.; Shkolnikov, Vladimir M. 2005: Official population statistics and the Human Mortality Database estimates of populations aged 80+ in Germany and nine other European countries. In: Demographic Research 13: 335362 [doi: 10.4054/DemRes.2005.13.14].

Kaus, Wolfhard; Mundil-Schwarz, Rabea 2015: Die Ermittlung der Einwohnerzahlen und der demografischen Strukturen nach dem Zensus 2011. In: Wirtschaft und Statistik 2015/4: 18-38 [https://www.destatis.de/DE/Publikationen/WirtschaftStatistik/2015/04/ ErmittlungEinwohnerzahlen_042015.pdf?_blob=publicationFile, 25.07.2016].

Kibele, Eva; Scholz, Rembrandt D.; Shkolnikov, Vladimir M. 2008: Low migrant mortality in Germany for men aged 65 and older: Fact or artifact? In: European Journal of Epidemiology 23,6: 389-393 [doi: 10.1007/s10654-008-9247-1].

Manke, Matthias 2005: Die Volkszählungen des Großherzogtums Mecklenburg-Schwerin in den Jahren 1819 und 1867 unter Berücksichtigung der Volkszählung des Jahres 1866. In: Genealogie 54: 449-468.

Michel, Bernd 2004: Ergebnisse der Mehrfachprüfung im Rahmen des Zensustests. In: Wirtschaft und Statistik 2004/9: 978-991 [https://www.destatis.de/DE/Publikationen/WirtschaftStatistik/Zensus/MehrFachfallPruefung.pdf? _blob=publicationFile 25.07.2016].

Michel, Harald 1985: Volkszählungen in Deutschland. Die Erfassung des Bevölkerungsstandes von 1816 bis 1933. In: Jahrbuch für Wirtschaftsgeschichte 1985/2: 79-91.

Oettel, Andreas 2006: Zur Geschichte der amtlichen Statistik in der Sowjetischen Besatzungszone und der DDR 1945-1990. In: Statistik in Sachsen 1: 49-55.

Pötzsch, Olga 2016: Fertility in Germany before and after the 2011 Census: Still no Trend Reversal in Sight. In: Comparative Population Studies 41,1: 87-118 [doi: 10.12765/ CPoS-2016-02en]

Prewitt, Kenneth 2003: Politics and Science in Census Taking. New York, Washington: Russell Sage Foundation.

Rendtel, Ulrich 2015: Warum im Zensus die Ergebnisse der Stichprobenmethode keine Benachteiligung der großen Gemeinden darstellen. Eine Detektivarbeit. Fachbereich Wirtschaftswissenschaft; Diskussionsbeiträge Economics 2015/24 [https://github. com/DerSpiegel/datenlese/tree/master/Zensus_2011] [http://edocs.fu-berlin.de/docs/ servlets/MCRFileNodeServlet/FUDOCS derivate 000000005297/discpaper2015 24 pdf;jsessionid=BBBC272A205E6C2CA2C̄5432A97D84F26?hosts=, 22.08.2016] .

Rennefanz, Sabine; Zylka, Regine 2013: Zensus: Wowereit bezweifelt Zensus-Daten. Berliner Zeitung vom 14. Juni 2013 [http://www.berliner-zeitung.de/berlin/zensus-wowereit-bezweifelt-zensus-daten-5464458].

Rothenbacher, Franz 1997: Historische Haushalts- und Familienstatistik von Deutschland 1815-1990. Frankfurt/New York: Campus Verlag.

Scholz, Rembrandt D. 2013: Zur demographischen Entwicklung der Hansestadt Rostock im 19. Jahrhundert. In: Busch, Michael; Kroll, Stefan; Scholz, Rembrandt D. (Eds.): Geschichte - Kartographie - Demographie: Historisch-Geographische Informationssysteme im methodischen Vergleich. Münster: LIT Verlag. 
Statistische Ämter des Bundes und der Länder 2004: Ergebnisse des Zensustests. In: Wirtschaft und Statistik 8/2004: 813-833 [https://www.destatis.de/DE/Publikationen/ WirtschaftStatistik/Zensus/Test_Ergebnisse.pdf?_blob=publicationFile, 25.07.2016].

Statistisches Bundesamt 1999: DDR-Statistik. Grundlagen, Methoden und Organisation der amtlichen Statistik der DDR. 1949-1990. Sonderreihe mit Beiträgen für das Gebiet der ehemaligen DDR. Wiesbaden: Statistisches Bundesamt.

Statistisches Bundesamt 2013a: Bevölkerung und Erwerbstätigkeit. Natürliche Bevölkerungsbewegung. Fachserie 1 Reihe 1.1 2011. Statistisches Bundesamt (9. April 2013). Pflegestatistik 2011, Deutschlandergebnisse (18. Januar 2013).

Statistisches Bundesamt 2013b: Gemeindeverzeichnis-Sonderveröffentlichung. Gebietsstand: 31.12.2011 (Jahr). Alle politisch selbständigen Gemeinden in Deutschland nach Bevölkerung am 31.12.2011 auf Grundlage des Zensus 2011 und früherer Zählungen. Aktualisiert auf Zensusdaten mit dem Stand vom 10.04.2014 im April 2014. Wiesbaden.

Statistisches Bundesamt 2014a: Downloadtabelle „Bevölkerung nach Alter in Jahren und Geschlecht für Gemeinden. Ergebnisse des Zensus am 9. Mai 2011. Version 1.04.2014".

Statistisches Bundesamt 2014b: Downloadtabelle „Bevölkerung nach Staat der Staatsangehörigkeit und Geschlecht für Gemeinden. Ergebnisse des Zensus am 9. Mai 2011. Version 1.04.2014".

Statistisches Bundesamt 2014c: Ergebnisse des Zensus 2011 [https://www.zensus2011. de/SharedDocs/Aktuelles/Ergebnisse/DemografischeGrunddaten.html?nn=3065474, 20.10.2015].

Statistisches Bundesamt 2015: Zensus 2011. Methoden und Verfahren. Wiesbaden: Statistisches Bundesamt [https://www.destatis.de/DE/Publikationen/Thematisch/Bevoelkerung/Zensus/ZensusBuLaMethodenVerfahren5121105119004.pdf;jsessionid=A92 71602B2171604AFD6094A7197CAD2.cae1?__blob=publicationFile, 25.07.2016].

Statistisches Bundesamt 2016: Zu den Klagen und Widerspruchsverfahren der Kommunen [https://www.zensus2011.de/SharedDocs/Aktuelles/KlagenUndWiderspruchsverfahren.html, 25.07.2016].

Vorndran, Ingeborg 2004: Zensustest-Verfahren und Ergebnisse der Haushaltegenerierung. In: Wirtschaft und Statistik 2004/11: 1245-1255 [https://www.destatis. de/DE/Publikationen/WirtschaftStatistik/Zensus/VerfahrenErgebnisse.pdf? blob=publicationFile; 25.07.2016].

Wietog, Jutta 2001: Volkszählung unter dem Nationalsozialismus. Berlin: Duncker und Humblot.

Zahn, Friedrich 1900: Die praktische Bedeutung der deutschen Volkszählung. In: Jahrbücher für Nationalökonomie und Statistik 20: 577-592.

ZensG 2011 Zensusgesetz (ZensG 2011) in der Fassung vom 8. Juli 2009 [https:// www.zensus2011.de/SharedDocs/Downloads/DE/Gesetze/Zensusgesetz_2011.html, 25.07.2016]

Zhang, Li-Chun; Hendriks, Coen 2012: Micro integration of register-based census data for dwelling and household. United Nations Economic Commission for Europe. Conference of European Statisticians. Oslo, Norwegen, 24-26. September 2012.

zur Nieden, Felix; Sommer, Bettina 2016: Life Expectancy in Germany Based on the 2011 Census: Was the Healthy Migrant Effect Merely an Artefact? In: Comparative Population Studies 41,2: 145-174 [doi: 10.12765/CPoS-2016-05en]. 
196 - Rembrandt Scholz, Michaela Kreyenfeld

Dr. Rembrandt Scholz. Max-Planck-Institute for demographic Research. Rostock, Germany. E-mail: scholz@demogr.mpg.de URL: http://www.demogr.mpg.de/en/institute/staff_directory_1899/rembrandt_d_ scholz_663.htm

Prof. Dr. Michaela Kreyenfeld ( $₫)$. Hertie School of Governance. Berlin, Germany. E-mail: kreyenfeld@hertie-school.org

URL: https://www.hertie-school.org/kreyenfeld/ 


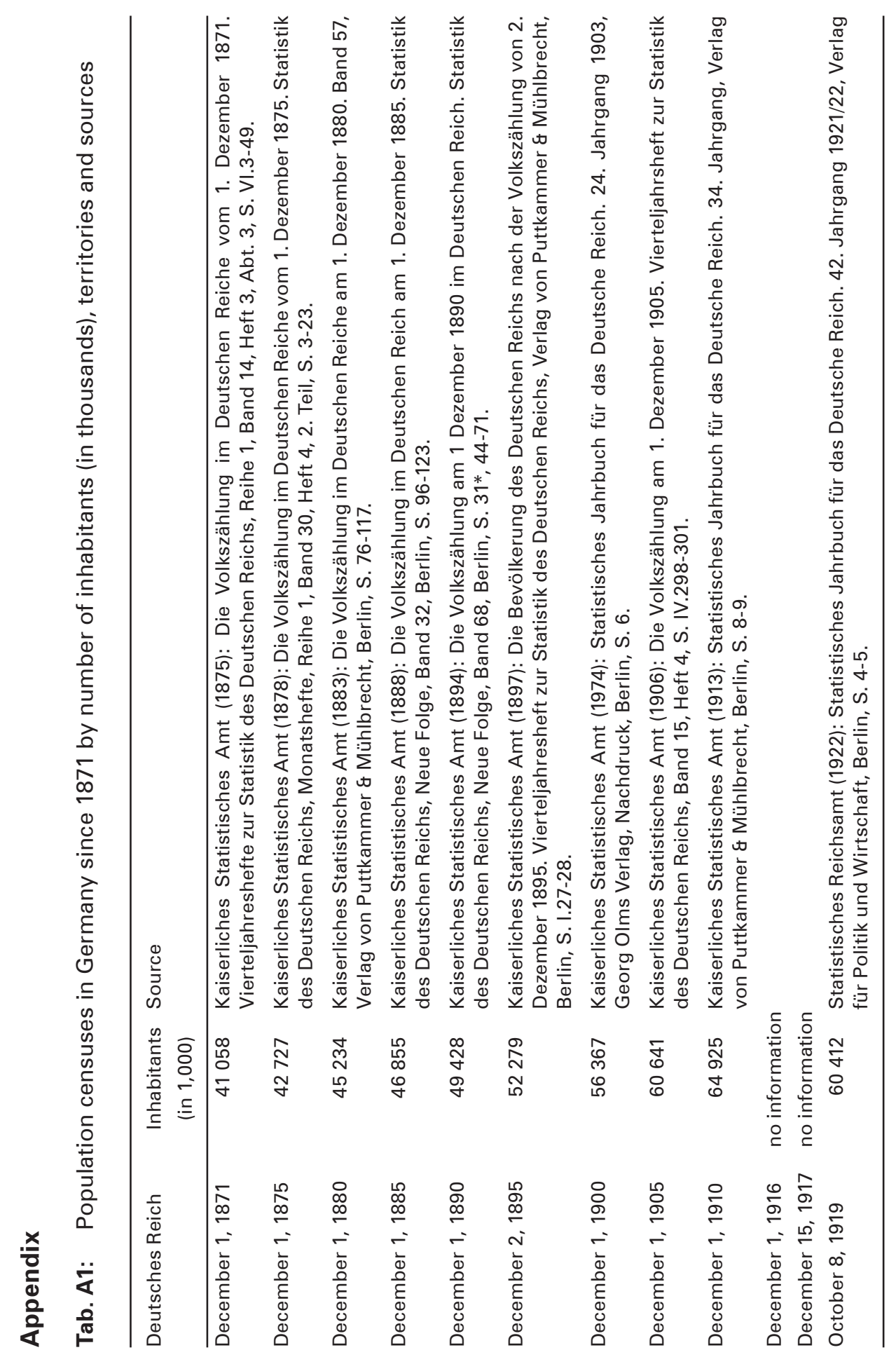


The Register-based Census in Germany 199

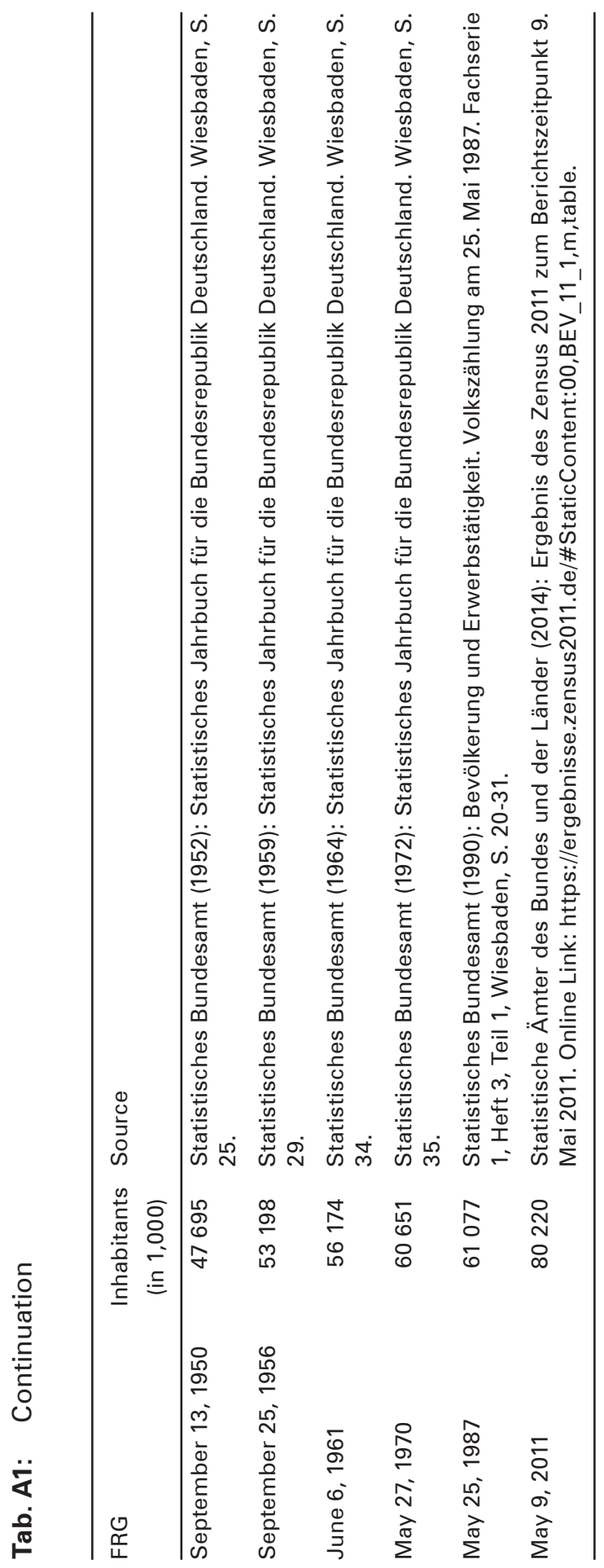




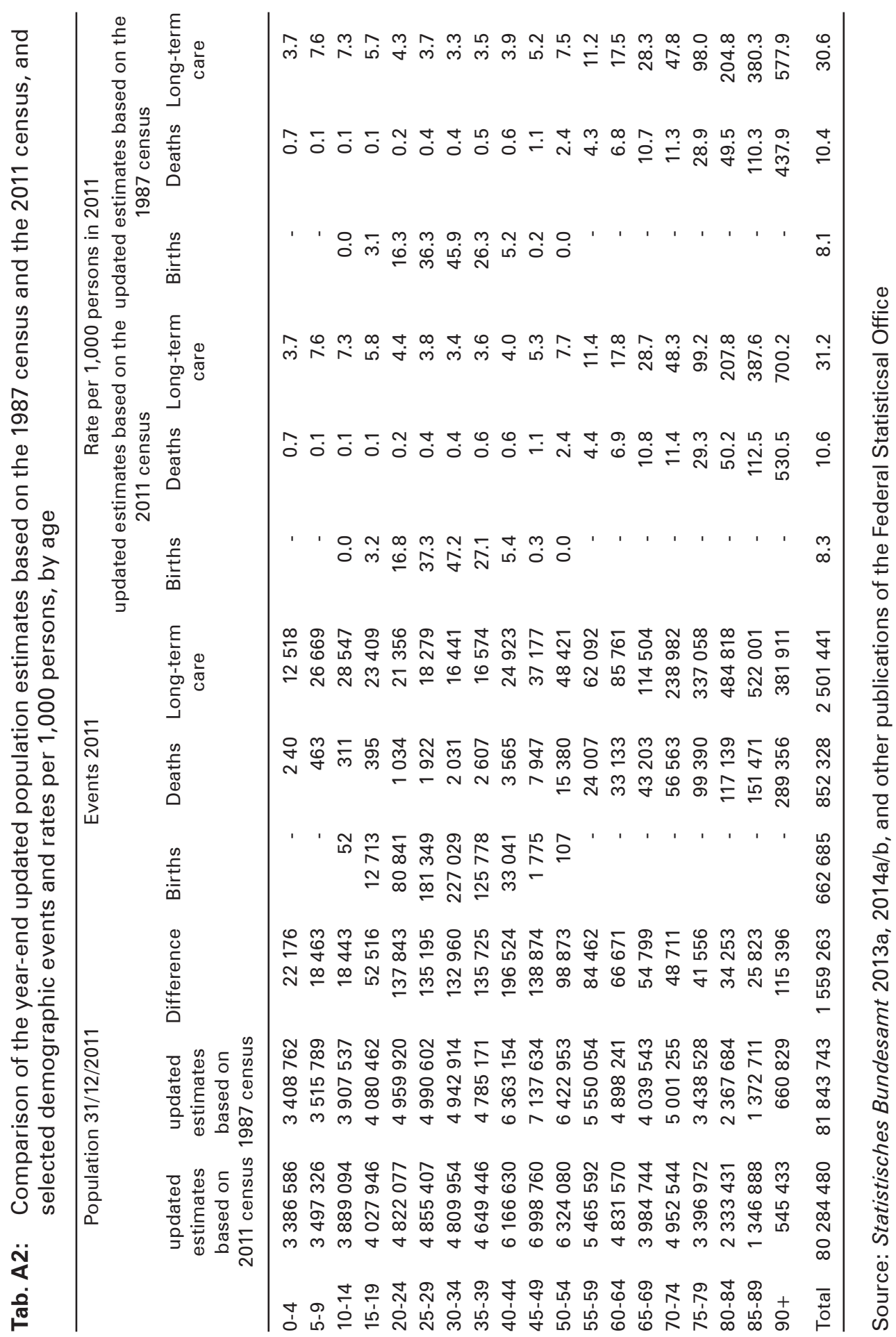


Fig. A1: Number of municipalities (ordinate) by relative difference between 2011 census and updated estimates based on the 1987 census (abscissa), by small municipalities (fewer than 10,000 inhabitants) and big municipalities $(10,000$ or more inhabitants) and by federal states, in $\%$

Baden-Wurttemberg

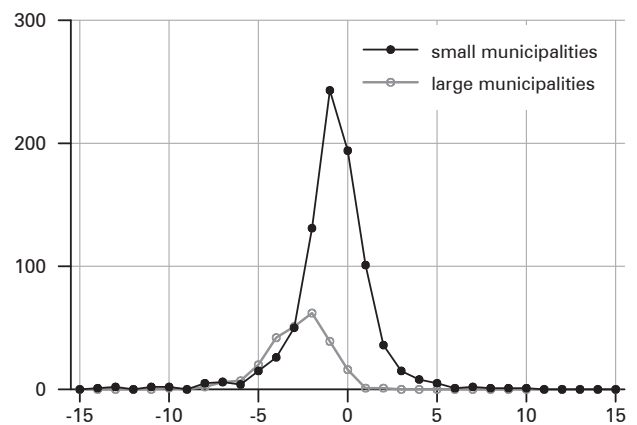

Brandenburg

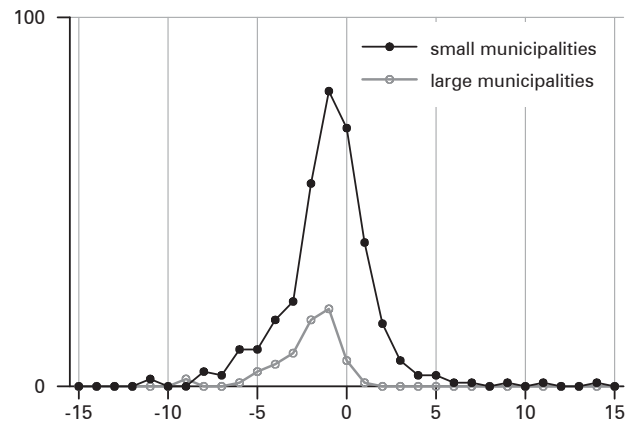

Mecklenburg-Vorpommern

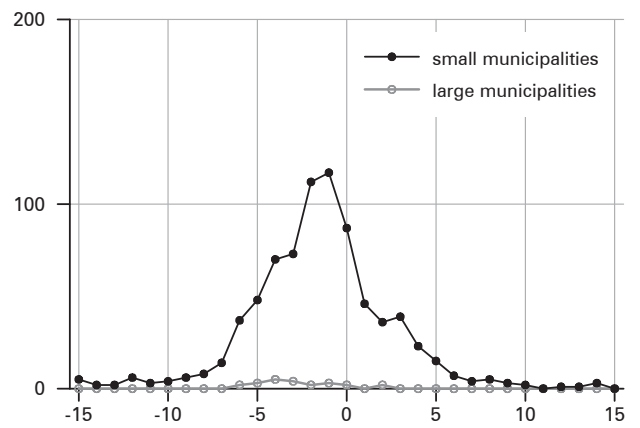

Bavaria

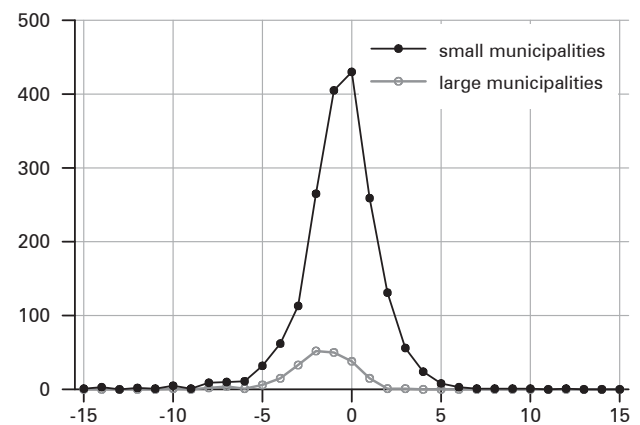

Hesse

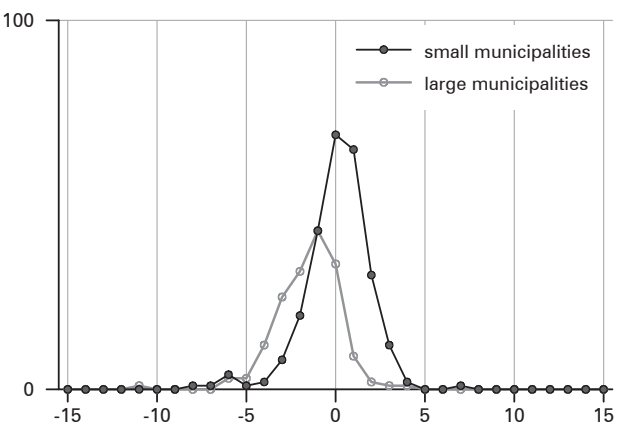

Lower Saxony

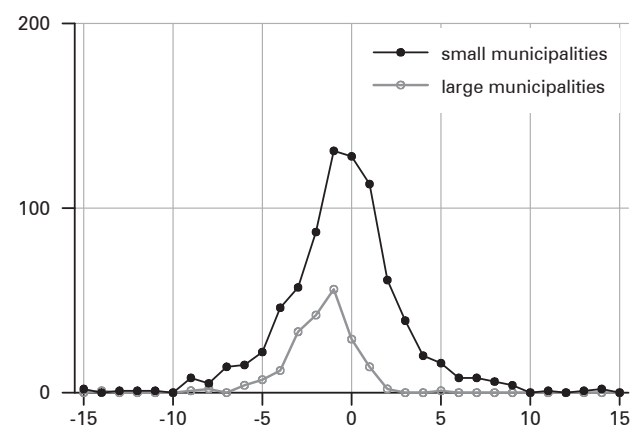


Fig. A1: Continuation
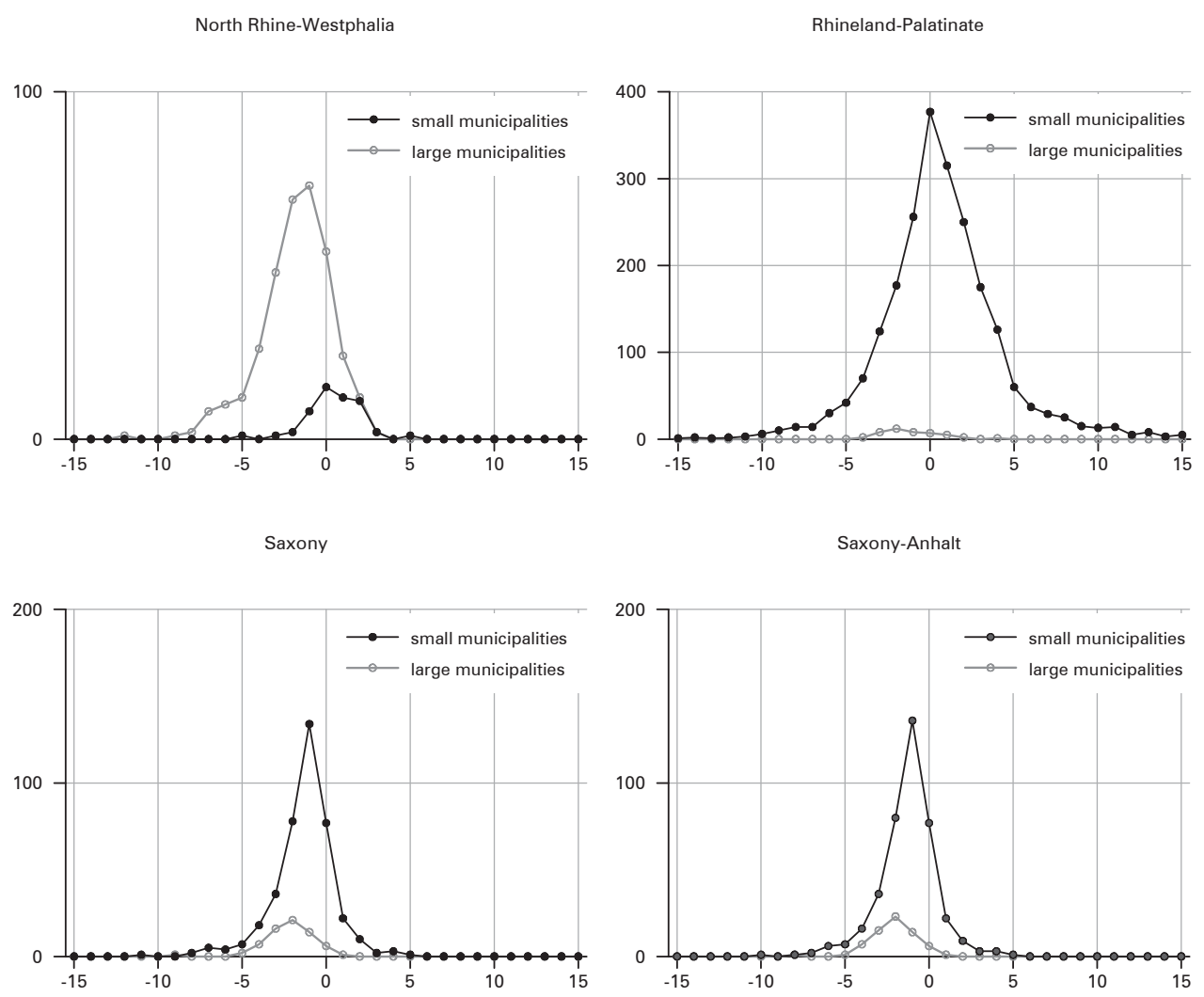

Schleswig-Holstein

Thuringia
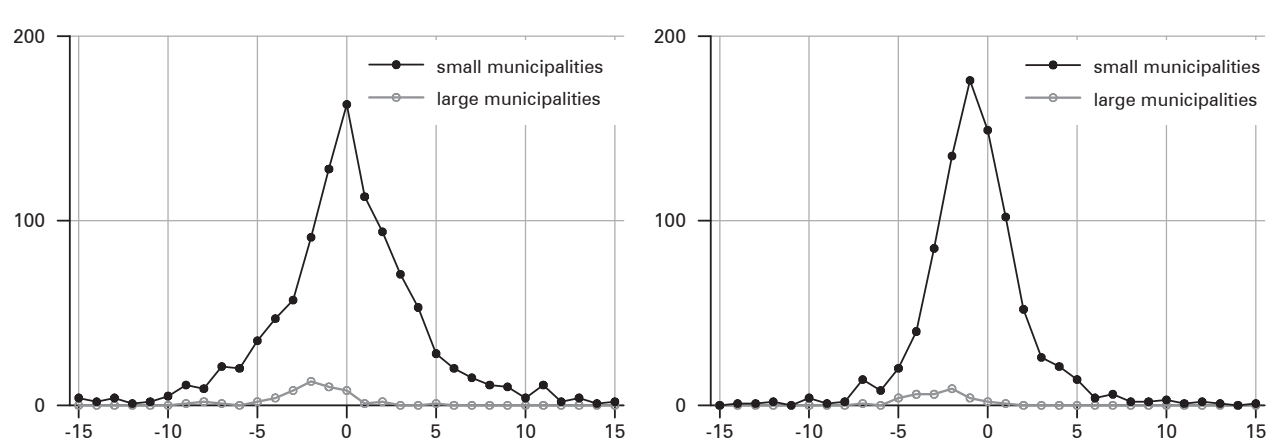

Note: Berlin, Hamburg, and Bremen were not included in the figure because there is no variation by municipalities for city states. Saarland was excluded because of the low number of municipalities for this federal state.

Source: Statistisches Bundesamt 2013b 
Fig. A2: Relative deviation between 2011 census and updated estimates of 1987 census, by sex, age, and citizenship
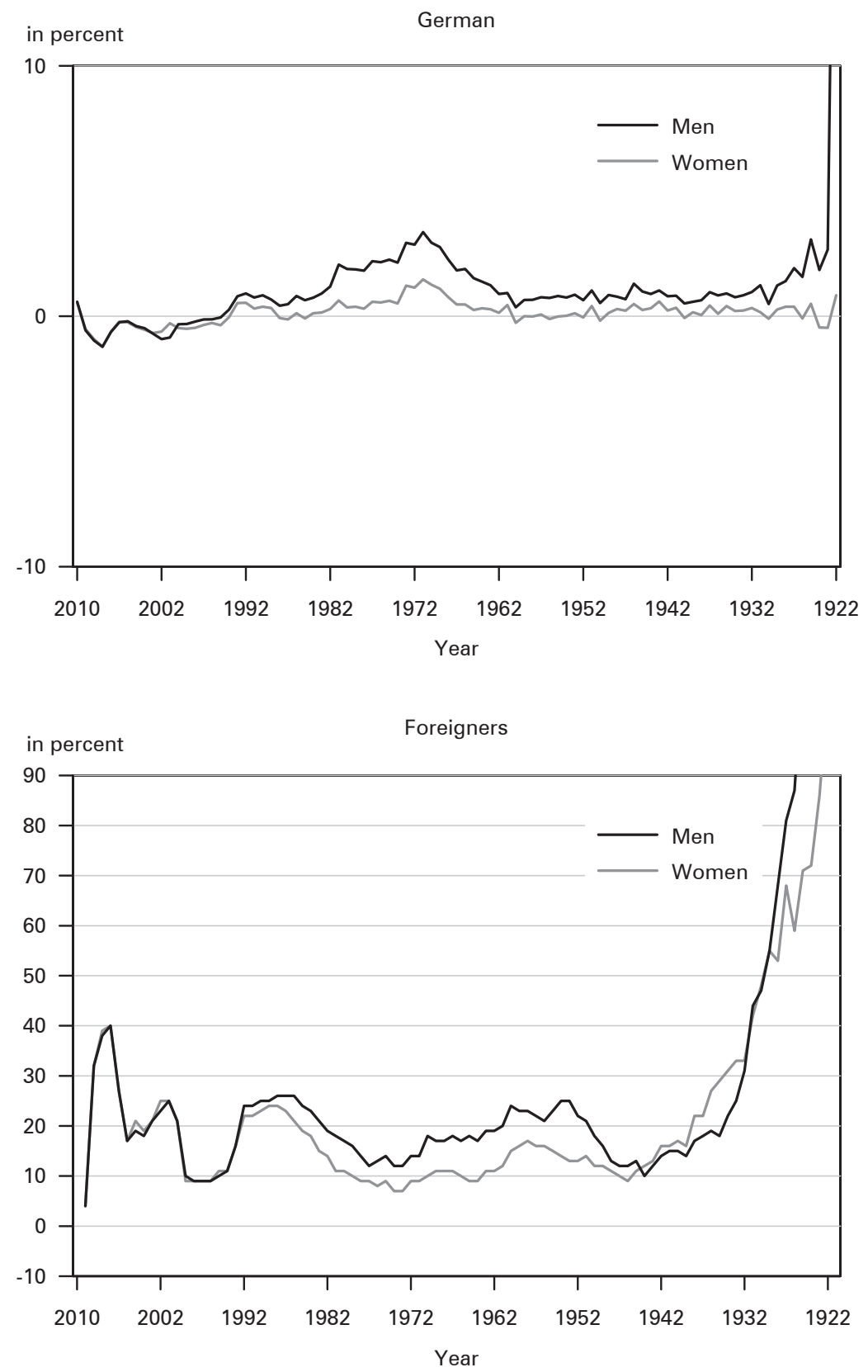

Source: Statistisches Bundesamt 2014 a/b 
Fig. A3: Relative distribution of the population by 1,000 (ordinate) by age (abscissa) and by size of municipality

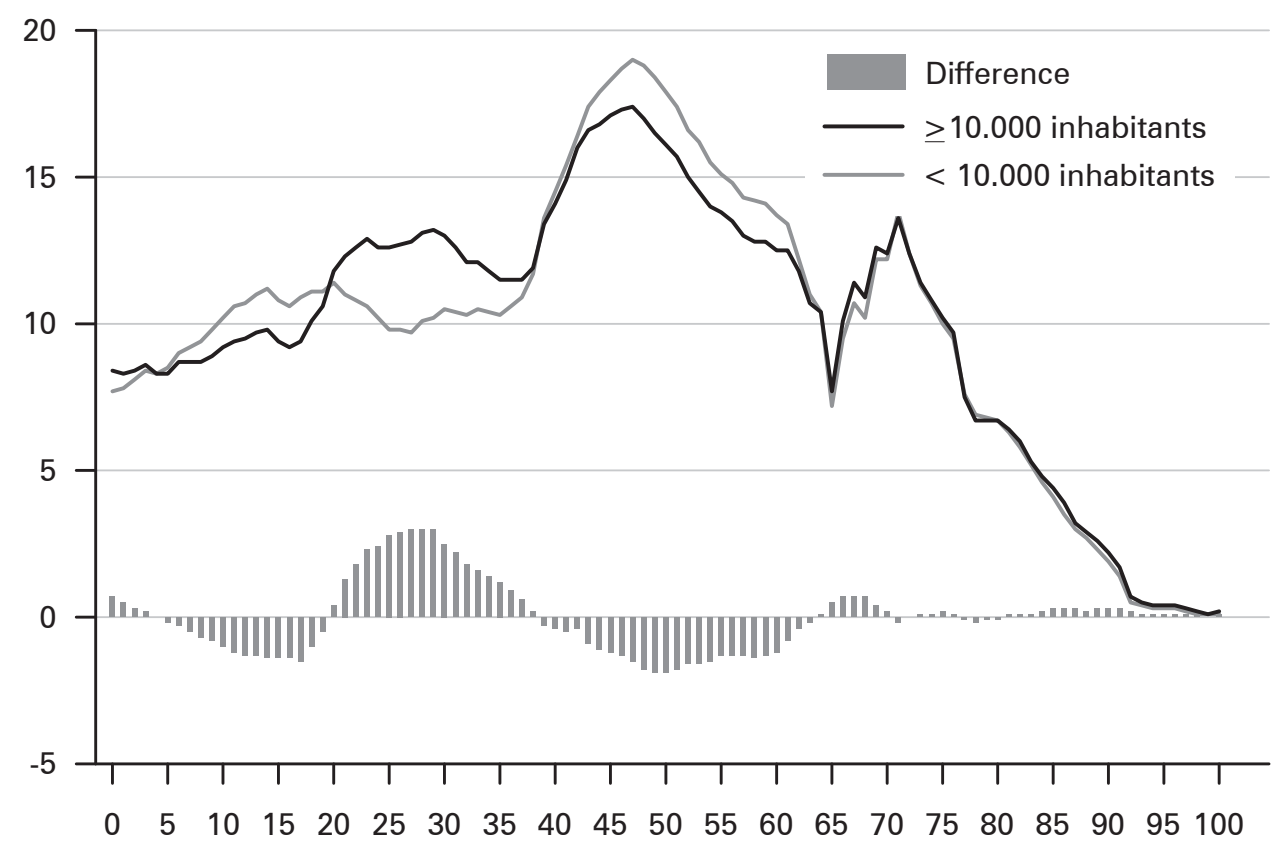

Source: Statistisches Bundesamt 2014b 


\section{Comparative Population Studies}

WWW.comparativepopulationstudies.de

ISSN: 1869-8980 (Print) - 1869-8999 (Internet)

Published by

Prof. Dr. Norbert F. Schneider

Federal Institute for Population Research D-65180 Wiesbaden / Germany

\section{(cc) BY-SA}

2016

\section{Managing Editor}

Frank Swiaczny

\section{Assistant Managing Editor}

Katrin Schiefer

\section{Copy Editor}

(Selected Articles in German)

Dr. Evelyn Grünheid

\section{Layout}

Beatriz Feiler-Fuchs

E-mail:cpos@bib.bund.de

\section{Scientific Advisory Board}

Paul Gans (Mannheim)

Karsten Hank (Köln)

Johannes Huinink (Bremen)

Michaela Kreyenfeld (Rostock)

Marc Luy (Wien)

Notburga Ott (Bochum)

Peter Preisendörfer (Mainz)

Nikola Sander (Groningen)

Zsolt Spéder (Budapest)

\section{Board of Reviewers}

Martin Abraham (Erlangen)

Laura Bernardi (Lausanne)

Hansjörg Bucher (Bonn)

Claudia Diehl (Konstanz)

Andreas Diekmann (Zürich)

Gabriele Doblhammer-Reiter (Rostock)

Jürgen Dorbritz (Wiesbaden)

Anette Eva Fasang (Berlin)

E.-Jürgen Flöthmann (Bielefeld)

Alexia Fürnkranz-Prskawetz (Wien)

Beat Fux (Salzburg)

Joshua Goldstein (Berkeley)

Sonja Haug (Regensburg)

Hill Kulu (Liverpool)

Aart C. Liefbroer (Den Haag)

Kurt Lüscher (Konstanz)

Emma Lundholm (Umeå)

Nadja Milewski (Rostock)

Dimiter Philipov (Wien)

Roland Rau (Rostock)

Tomáš Sobotka (Wien) Jeroen Spijker (Barcelona)

Olivier Thévenon (Paris)

Helga de Valk (Brussel)

Heike Trappe (Rostock)

Michael Wagner (Köln) 